\title{
High Hydrostatic Pressure Treatment Ensures the Microbiological Safety of Human Milk Including Bacillus cereus and Preservation of Bioactive Proteins Including Lipase and Immuno-Proteins: A Narrative Review
}

\author{
Claude Billeaud (D)
}

check for updates

Citation: Billeaud, C. High Hydrostatic Pressure Treatment Ensures the Microbiological Safety of Human Milk Including Bacillus cereus and Preservation of Bioactive Proteins Including Lipase and Immuno-Proteins: A Narrative Review. Foods 2021, 10, 1327. https:/ / doi.org/10.3390/foods10061327

Academic Editor: Christopher John Smith

Received: 23 April 2021

Accepted: 7 June 2021

Published: 9 June 2021

Publisher's Note: MDPI stays neutral with regard to jurisdictional claims in published maps and institutional affiliations.

Copyright: (C) 2021 by the author. Licensee MDPI, Basel, Switzerland. This article is an open access article distributed under the terms and conditions of the Creative Commons Attribution (CC BY) license (https:// creativecommons.org/licenses/by/ $4.0 /)$
Neonatology \& Nutrition, CIC Pédiatrique 1401, INSERM, Hopital des Enfants, CHU Pellegrin Place Amelie Raba Leon, 33076 Bordeaux, France; claude.billeaud@chu-bordeaux.fr; Tel.: +33-688-237-374

\begin{abstract}
Breast milk is the nutritional reference for the child and especially for the preterm infant. Breast milk is better than donated breast milk (DHM), but if breast milk is not available, DHM is distributed by the Human Milk Bank (HMB). Raw Human Milk is better than HMB milk, but it may contain dangerous germs, so it is usually milk pasteurized by a Holder treatment $\left(62.5{ }^{\circ} \mathrm{C}\right.$ $30 \mathrm{~min}$ ). However, Holder does not destroy all germs, and in particular, in $7 \%$ to $14 \%$, the spores of Bacillus cereus are found, and it also destroys the microbiota, lipase BSSL and immune proteins. Another technique, High-Temperature Short Time (HTST $72{ }^{\circ} \mathrm{C}, 5-15 \mathrm{~s}$ ), has been tried, which is imperfect, does not destroy Bacillus cereus, but degrades the lipase and partially the immune proteins. Therefore, techniques that do not treat by temperature have been proposed. For more than 25 years, high hydrostatic pressure has been tried with pressures from 100 to $800 \mathrm{MPa}$. Pressures above $400 \mathrm{MPa}$ can alter the immune proteins without destroying the Bacillus cereus. We propose a High Hydrostatic Pressure (HHP) with four pressure cycles ranging from 50-150 MPa to promote Bacillus cereus germination and a $350 \mathrm{MPa}$ Pressure that destroys $10^{6}$ Bacillus cereus and retains $80-100 \%$ of lipase, lysozyme, lactoferrin and $64 \%$ of IgAs. Other HHP techniques are being tested. We propose a literature review of these techniques.
\end{abstract}

Keywords: HHP; breast milk; Bacillus cereus; human milk bank; lipase

\section{Introduction}

Breast milk is the standard nutrient appropriate for infant development and especially for preterm. Breast milk is the best, but it is not always available, so breast milk provided by breast milk banks (HMB) is sometimes used [1]. In this study, we present the problem of contamination treatment to eliminate pathogen contamination. The optimal method eliminates all pathogens, including Bacillus cereus spores, and preserves the bioactive components of donated breast milk: fat absorption enhancing HM lipase and immune proteins (lysozyme, lactoferrin and IgAs).The main process used to pasteurize donated breast milk (DHM) is heat treatment, i.e., the Holder process-low-temperature long time (LTLT, $62.5^{\circ} \mathrm{C}, 30 \mathrm{~min}$ ) [2] and high-temperature short time (HTST, $72{ }^{\circ} \mathrm{C}, 5-15 \mathrm{~s}$ ) and has been recently studied.

Neither of these processes destroys bacterial spores. In addition, LTLT alters the activity of many HM components (enzymatic, nutritional or immune components).

Over the past 25 years, high hydrostatic pressure has been developed primarily for food processing.

Different assays to apply high hydrostatic pressure (HHP) treatment to the decontamination of breast milk have been tested in recent years. Nevertheless, these studies were partial and did not lead to any specific process able to give an appropriate answer to the challenge (irreversible inactivation of all pathogens while preserving the activity of the component). 
We found that an appropriate combination of different parameters characterizing the application of pressure (pressurization rate and latency period) at low-temperature $\left(38^{\circ} \mathrm{C}\right)$ could lead to the inactivation of both vegetative and spore forms [3]. In order to achieve conditions that preserve the maximum activity of the breast milk components, a temperature close to that of the human body was chosen. In this study, we provide a review of the properties of different methods as well as the properties of HHP.

\section{Heat Treatment of Human Milk}

\subsection{Holder Pasteurization}

Now, pasteurization of milk is an essential step to inactivate pathogens and part of the microbiota. It is the most commonly used pasteurization in HMBs LTLT, also known as Holder pasteurization $\left(62^{\circ} 5-30^{\prime}\right)$. However, this heat treatment can degrade biochemical components, such as IgAs, lactoferrin, some trace elements and several vitamins (Da Cost Evans [4]; Koenig [5]; It can also decrease the antioxidant capacity of milk, and it completely inactivates the lipase (Henderson [6]). Because of these losses, data supporting the use of pasteurized DHM as the sole diet for preterm, sick or preterm infants are incomplete. Cytokine concentrations also decrease after pasteurization, and there is a suggestion that more pro-inflammatory - rather than anti-inflammatory-cytokines. After LTLT pasteurization, there is a significant decrease in the concentrations of ascorbic, dehydroascorbic acid, $\alpha$-tocopherol and $\gamma$-tocopherol. However, milk fatty acids, including long-chain polyunsaturated fatty acids, are not affected. Heat treatment of DHM implies a decrease in its antioxidant properties; however, if necessary, HTST should be the method of choice in terms of DHM oxidative status (Silvestre [7]). To improve the nutritional quality of processed donor HM, treatments other than Holder pasteurization need to be explored.

\subsection{High-Temperature Short Time (HTST)}

High-temperature processing (HTST) is another rapid heating strategy $\left(72{ }^{\circ} \mathrm{C} \times 5-15 \mathrm{~s}\right)$.

It is a method that seems better to LTLT (G Moro [8]). However, this process does not destroy spores, and the safety does not reach that of HPP, which is the only process that combines the safety of nutritional and biological quality of DHM. In addition, HTST requires a technological investment and is only available at the industrial level.

It has been reported that there is a $0-20 \%$ loss of $\operatorname{sig} \mathrm{A}$, a $0-25 \%$ loss of total $\operatorname{IgA}$, a 0-85\% loss of lactoferrin and a total loss of lipase after STHT treatment (Goldblum [9]). There are variable effects of the HTST treatment on the lysozyme content of milk, ranging from a $20 \%$ to $40 \%$ loss. Chantry [10] showed that the IgA concentration measured after flash heating was almost identical to that reported by Goldblum [9] (a decrease in IgA concentration from 0.37 to $0.30 \mathrm{mg} / \mathrm{mL})(19 \%)$ after heating breast milk to $72{ }^{\circ} \mathrm{C}$ for $15 \mathrm{~s}$. Thus, all forms of heat treatment for the HM donor affect many milk components and, presumably, their efficacy. For this reason, treatment methods other than heat treatment should be explored.

\section{High-Pressure Processing}

\subsection{High-Pressure Processing and Pathogens}

\subsubsection{High-Pressure Processing (HPP)}

HPP can be used as the non-thermal pasteurization of foods, and it can inactivate microorganisms (Balci [11], Chawla et al. [12], Rendueles et al. [13]), producing safe and minimally processed foods with satisfactory and organoleptic qualities.

High-pressure processing (HPP) (100-800 MPa) is one of the most promising methods, processing and preserving foods at room temperature (Cheftel [14]; San Martin [15]).

Research into the application of HPP for milk preservation began with Hite [16]. He extended it to milk and other food pressure treatment.

Advances in materials science and the metallurgical industries in the use of HPP techniques during the period 1955-1980 enabled industrial applications in the biosciences (Demazeau 2008 [17]). 
In the mid-1980s, HP processes were renewed in Japan to ensure microbial safety of food (Hayashi [18]) in France (Demazeau and Rivalain [19]).

The first commercial products treated under HHP conditions appeared on the market in 1991. Today, thanks to the progress made in the knowledge of the behavior of food constituents under high-pressure conditions and in the development of high-pressure industrial equipment, HHP-treated food products are available in many countries and many products include plant $(36 \%)$, meat $(31 \%)$, juices $(11 \%)$, seafood and fish $(16 \%)$ and other products $(6 \%)$.

\subsubsection{Comparison of HM Composition Treated by Pasteurization or High-Pressure}

HPP uses water or a mixture of water and glycol as a means of transmitting pressures between 100 and $800 \mathrm{MPa}$ to the milk (Trujillo [20]). Due to the low energy resulting from the application of HHP on liquid phases, only weak bonds can be affected. Therefore, small molecules, such as amino acids and vitamins, are not affected (Balci [11]; Lullien-Pellerin [21]). HPP can denature whey (Moatsou. [22]). However, Viazis, 2007 [23] demonstrated that HHP could better maintain IgA and lysozyme in HM than Holder pasteurization, and Permanyer [24] confirmed that IgAs, could be better maintained after HHP than after Holder pasteurization. Viazis, 2008 [25] was the first to show that HHP could inactivate five selected bacterial pathogens in breast milk. All these pioneers suggest that HHP may be a potential alternative to Holder pasteurization in HMB. However, we need studies on the effects of HHP on other components of DHM.

One study compared the effects of LTLT and HHP on fatty acid composition and on vitamin C and tocopherol in DHM (Moltó-Puigmartí [26]). In addition, Contador [27] and Delgado et al [28] varied the pressure (300, 600 and $900 \mathrm{MPa})$ and temperature $(50,65$ and $80^{\circ} \mathrm{C}$ ) and studied the levels of tocopherols, fatty acids, cytokines, leukocytes and immunoglobulins (IgM, IgA and IgG) in the DHM. Treatment of breast milk at $65^{\circ} \mathrm{C}$ and $80^{\circ} \mathrm{C}$, regardless of the pressure value, induced a decrease in $\alpha$-tocopherol compared with untreated milk. The fatty acid content varied with the highest pressure values (600 and $900 \mathrm{MPa})$ and the highest temperatures $\left(65^{\circ} \mathrm{C}\right.$ and $\left.80^{\circ} \mathrm{C}\right)$. On the other hand, HHP had a minimal effect on some cytokines, IL-2, IL-17 and IFN- $\gamma$. Leukocytes are highly affected by both HHP and thermal treatments. Only the treatment under $300 \mathrm{MPa}$ and $50{ }^{\circ} \mathrm{C}$ maintained some immunoglobulin levels (IgM 75\%, Ig 48\% and IgG 100\% retention).

Contador et al. [27] compared LTLT pasteurization $\left(62.5^{\circ} \mathrm{C}-30 \mathrm{~min}\right)$ to HHP $(400$ or $600 \mathrm{MPa}$ for 3 or $6 \mathrm{~min}$ ) on immune cells (leukocyte content) and immunoglobulin content (IgM, IgA and IgG). HHP at $400 \mathrm{MPa}$ (for 3 or $6 \mathrm{~min}$ ) better maintained the original immunoglobulin levels. HHP at $400 \mathrm{MPa}$ appeared to preserve leukocytes more (10-14\%) than LTLT. HPP would be better to maintain various components of DHM (compared with LTLT). The lipase, particularly, is destroyed when it is over $40{ }^{\circ} \mathrm{C}$ and preserved even at $600 \mathrm{MPa}$. So, at $62.5^{\circ}$ (LTLT), it is completely destroyed.

In milk (Johnston [29]), the pressure-induced dissociation of colloidal calcium phosphate and the denaturation of milk serum proteins can change and/or improve its technological properties. In addition to microbial destruction, the effects of HHP on protein structure and mineral balance suggest (Devi [30]) different applications on the production of cheese and yogurt and the preparation of dairy products with new textures (MartínezRodríguez [31]). When milk is subjected to HHP, casein micelles are disintegrated into smaller particles (Johnston [29]). This results in an increase in caseins and whey proteins that become sedimentable by centrifugation and precipitable at $\mathrm{pH}$ 4.6. Law [32] reported that after pressure treatment up to $500 \mathrm{MPa}$ at $25^{\circ} \mathrm{C}$, $\beta$-lactoglobulin is the most easily denatured serum protein. Denaturation of immunoglobulins and $\alpha$-lactalbumin occurs only at the highest pressures and at temperatures from $50{ }^{\circ} \mathrm{C}$.

An important study was devoted to the effects of HHP on the structure and dynamics of $\beta$-lactoglobulin (Russo [33]). In this study, the structural results of a high-pressure unfolding of $\beta$-lactoglobulin are observed above a value of $300 \mathrm{MPa} I$ (Gosch [34]). The highly variable microbial quality of raw colostrum and its heat-sensitive nature complicate 
the preparation of safe colostrum products for human use. A new process combining microfiltration $(1.4-0.8 \mu \mathrm{m})$ and HHP $(400-500 \mathrm{MPa}, 10 \mathrm{~min})$ can lead to a significant microbial reduction. Calcium phosphate solubility decreases with increasing temperature and increases with pressure (Buchheim [35]).

Studies by Gervilla [36] on the free fatty acid (FFA) content of sheep's milk showed that $\mathrm{HHP}$ at $100-500 \mathrm{MPa}$ at 4,25 and $50^{\circ} \mathrm{C}$ did not increase lipolysis. Even some treatments at $50{ }^{\circ} \mathrm{C}$ showed a lower FFA content than fresh raw milk. This phenomenon avoids flavors derived from the lipolytic rancidity of milk. Hydrostatic pressure up to $500 \mathrm{MPa}$ causes changes in the size and distribution of milk fat globules in sheep's milk. HPP at 25 and $50{ }^{\circ} \mathrm{C}$ showed a tendency to increase the number of small globules in the 1-2 $\mu \mathrm{m}$ range, whereas at $4{ }^{\circ} \mathrm{C}$ this tendency was reversed, but no damage to the milk fat globule membrane occurred. In contrast, a study on goat milk revealed that lipoprotein lipase was somewhat resistant to pressurization (Buffa [37]). It should be noted that in human milk, there is not only lipoprotein lipase but also BSSL.

Lactose in milk can be isomerized into lactulose by heating, and then transformed into acids and sugars. On the other hand, HHP does not cause degradation of these compounds after pressurization (100-400 MPa; $10-60 \mathrm{~min}$ at $25^{\circ} \mathrm{C}$ ). No Maillard reaction or lactose isomerization occurs in milk after HHP (Lopez [38]). Milk with casein micelles of reduced diameter improves the coagulation properties. The disintegration of the micelles produced by HHP changes the color of the milk (Lopez [38]; Buffa [37]). There is a decrease in lightness $\left(\mathrm{L}^{*}\right)$ and an increase in greenness $\left(\mathrm{b}^{*}\right)$ and yellowness $\left(\mathrm{Y}^{*}\right)$ of HPP-treated sheep milk (Gervilla [39]). The decrease in $\mathrm{L}^{*}$ value due to the disintegration of casein micelles by HHP into small fragments increases the translucency of milk (Johnston [29]). This phenomenon was visually negligible in sheep's milk, which is important to avoid rejection by potential consumers.

Similar results were found by Mussa and Ramaswamy [40] in cow's milk, showing the low sensitivity of milk color to pressure. Warming samples from 4 to $43{ }^{\circ} \mathrm{C}$ caused the color values of HPP milk to return to values of untreated HM (Needs [41]).

While both covalent and non-covalent bonds are affected by temperature, HHP at ambient temperatures disrupts only weak bonds, so small molecules such as vitamins, amino acids, simple sugars and flavors are not altered by HHP (Cheftel [42]). The DHM treatment with HPP at $400 \mathrm{MPa}$ does not result in loss of vitamins B1 and B6. GarciaGrael [43] found that HPP at $400 \mathrm{MPa}$ for $15 \mathrm{~min}$ at $40-60{ }^{\circ} \mathrm{C}$ reduced, and at $25-60{ }^{\circ} \mathrm{C}$ maintained the organoleptic properties of milk. So, this suggests that these treatments could produce milk with good sensory properties and increased preservation.

\subsubsection{HHP and Human Milk Safety \\ HHP and Bacteria}

The resistance of pathogens to pressure in food is highly variable depending on the parameters of HHP (Pressure, Cycles, Temperature), the type of food, the properties and the physiological state of the pathogen (Smelt [44]). Exponentially growing microbes are more sensitive to pressure than stationary phase pathogens. Spores are always more resistant than vegetative bacteria and can survive a pressure of $1000 \mathrm{MPa}$. Germination of spores can be stimulated by pressures of 50 to $150 \mathrm{MPa}$. The vegetative forms can then be killed by heat or gentle pressure treatments. Gram-positive organisms tend to be more resistant to pressure than Gram-negative organisms. However, a considerable variation in pressure resistance within strains of the same species has been demonstrated in both Gram-positive and Gram-negative microorganisms. There is considerable variation in pressure resistance within strains of the same species. Gram-positives require HHP of 500-600 MPa at $25^{\circ} \mathrm{C}$ for $10 \mathrm{~min}$ to be inactivated, whereas Gram-negatives are inactivated with pressures of $300-400 \mathrm{MPa}$ at $25^{\circ} \mathrm{C}$ for $10 \mathrm{~min}$. Recently, a Gram-positive bacterium (S. aureus) was inactivated at $200 \mathrm{MPa}$ in human blood plasma (Rivalain et al. [45]). Vegetative yeasts and molds are the most sensitive to pressure (Eperlan [44]). Numerous studies on the inactivation of pathogens in milk (naturally present or inoculated) by HPP have recently 
been performed and have shown that it is possible to obtain milk with a pressure of 400-600 MPa comparable to that of pasteurized milk $\left(72{ }^{\circ} \mathrm{C}, 15 \mathrm{~s}\right)$, depending on the microbiological quality of the milk (Kolakowski [46], Mussa [41]), but with exceptions due to HPP-resistant spores.

In addition, the combined efficacy of HHP with mild temperatures $\left(30-50^{\circ} \mathrm{C}\right)$ and / or with bacteriocins (nisin, pediocin, lacticin, etc.) on foodborne bacteria and spores was tested. Some of these combinations significantly improve the efficacy of HPP, sometimes showing synergistic inactivation between HPP and natural antimicrobial substances (Garcia Graells [43], Alpas [47]; Morgan [48]). Taking into account all the parameters of HP and temperature, we designed a specific high-pressure treatment of breast milk. The challenge was to inactivate the widest range of pathogens while preserving the activity of most of its major bioactive components in breast milk. We, therefore, developed this method, inoculating different germs in vegetative and/or spore form. As a result, in October 2012, we filed a French patent application (French patent 12.60215 HPBioTECH, filed 26 October 2012) by HPBioTECH and the Bordeaux University Hospital.

\section{Effects on Bacteria and Yeasts}

For the past 30 years, the pressure inactivation of microorganisms has been developed in biosciences, in particular for foods and more recently for biological products, including pharmaceuticals. In many past studies, the effect of HHP on pathogens focused mainly on the effect of an increase in the pressure value. To assure the safety of pharmaceutical products containing fragile therapeutic components, the development of new decontamination processes at minimal pressure values is needed to maintain their therapeutic properties (Rigaldie et al. [49]).

The effect of HPP parameters was evaluated on the inactivation of Staphylococcus aureus ATCC 6538, which is an opportunistic pathogen of important relevance in the medical, pharmaceutical and food domains.

\section{Effects on Bacterial Spores}

For 30 years, in many previous studies, the effect of HHP on pathogens focused mainly on the effect of a variation of HHP in food and fragile pharmaceutical products; the development of new processes at minimum pressure values, necessary to maintain their therapeutic properties (Reineke et al. [50,51]). The effect of HHP parameters was evaluated on the inactivation of Staphylococcus aureus ATCC 6538, which is important in the medical, pharmaceutical and food fields. Human blood plasma demonstrated a high inactivation rate (a $5 \log 10$ decrease) at a pressure level as low as $200 \mathrm{MPa}$. Complete inactivation was achieved under the following conditions: $\mathrm{PR}=50 \mathrm{MPa}, \mathrm{AM}=5 \times 2 \mathrm{~min}, \mathrm{~T}=-5^{\circ} \mathrm{C}$ and $\mathrm{p}=300 \mathrm{MPa}$.

\section{Effects on Viruses}

There is great diversity within the virus family (Norton [52]). They consist of a protein envelope, called a capsid, composed of a number of proteins (capsomers) that contain a central nucleic acid core. They may also contain a small number of enzymes necessary for their infectivity. The mechanisms of viral inactivation by HHP are related to dissociation and/or denaturation of the virus envelope (Silva et al. [53]. Even in the case of enveloped viruses, the envelope can be denatured (Nakagami [54]). It can be a very small alteration of capsid proteins (Kingsley [55]) or receptor recognition proteins (Pontes et al. [56]), which leads to a loss of infectivity. The range of structural diversity involved is reflected in a wide diversity of pressure resistance (Smelt 1998 [45]). The most common human viruses are Norwalk type virus (SRSV), hepatitis A, rotavirus and astrovirus. Inactivation of feline calicivirus, adenovirus and hepatitis A can be achieved by treatment at $275 \mathrm{MPa}$ for $5 \mathrm{~min}$, $400 \mathrm{MPa}$ for $15 \mathrm{~min}$ and $450 \mathrm{MPa}$ for $5 \mathrm{~min}$ (Kingsley, 2002 [55]). A few studies have shown remarkable survival of poliovirus (Nakagami [54]). Foot-and-mouth disease virus was reduced by 102.9 units per treatment at $220 \mathrm{MPa}$ for $1 \mathrm{~h}$ (Kingsley et al. [55]). The mode of inactivation of viruses by HHP has not been fully explained, although the viral envelope 
seems to be a target for HHP inactivation. Electron microscopy showed that high pressure at $300 \mathrm{MPa}$ damaged the virus envelope and prevented virus particles from binding to cells. HPP holds promise for the inactivation of HSV-1, cytomegalovirus (Landolfo [57]) and other enveloped viruses (Nakagami [54]). Pressure-induced dissociation can be fully reversible or irreversible. HHP can also induce minor changes in viral structures without disassembling the whole particle (Gaspar [58]) but without infectivity.

\section{Comparison of Significant Different HHP in Development}

\subsection{The High Hydrostatic Pressure Process Developed by HPBioTECH \& CHU Bordeaux}

Demazeau G. [3] used a pressure value of $350 \mathrm{MPa}$, a pressurization rate PR of $1 \mathrm{MPa} / \mathrm{s}$ and a cyclic application mode MA (3 or 4 cycles with a plateau of 5 min for each cycle) combined with a latency period of $5 \mathrm{~min}$ and a temperature of $38^{\circ} \mathrm{C}$.

This equipment was used to set up the HHP treatment of human milk. The challenge was to combine all the parameters governing HHP in order to reach the highest microbial reduction (including bacterial spores) and the optimal preservation of the main components of human milk.

We first carried out a pilot study that analyzed the reproducibility of HHP, compared to LTLT and raw milk of the same mother, in a bacteriological and biological study.

\subsubsection{Inactivation of All Pathogens}

Efficacy on the total vegetative flora (rejected because of its important initial contamination, up to $10^{8} \mathrm{cfu} / \mathrm{mL}$ ). Efficacy on Staphylococcus aureus: total inactivation for an initial concentration was between $10^{6}$ and $10^{7} \mathrm{cfu} / \mathrm{mL}$. Efficacy on bacterial spores: the HHP process was evaluated in HM inoculated by bacterial spores (either Bacillus subtilis or Bacillus cereus). This process was able to inactivate up to $10^{6} \mathrm{cfu} / \mathrm{mL}$ for both species. Efficacy on viruses: the HHP process was tested on cytomegalovirus. Complete inactivation of CMV was observed with an initial viral particle content greater than 7 logs in breast milk after HHP application.. The HHP process irreversibly inactivates all pathogens, and the HHP-treated HM is microbiologically stable for a period of at least six months at a storage temperature of $-18{ }^{\circ} \mathrm{C}$. HM maintain complete sterility and lipase.

\subsubsection{Preservation of the HM Bioactive Components} Lipids

Lipase: The application of this HHP process led to the preservation of $88 \%$ of the lipase activity, while it was completely destroyed by LTLT pasteurization.

MFG (Milk Fat Globules) granulometry: In terms of size, the MFG population was of a bimodal type with a mean diameter (d4.3) MFG for milk (raw milk: $5.5 \mu \mathrm{m}$; LTLT: $5.6 \mu \mathrm{m}$; HHP: $5.4 \mu \mathrm{m})$. In addition, the proportion of "small" MFG was greater in raw milk and HHP milk $(\mathrm{d} 3.2=0.6$ vs. $0.8 \mu \mathrm{m}$, respectively $)$ than in LTLT breast milk $(\mathrm{d} 3.2=3.1 \mu \mathrm{m})$, whereas LTLT favors coalescence and thus the amount of "large" MFG.

Animal pilot study: the intestinal absorption of lipids in breast milk was measured in lymphatic duct cannulated rats fed either raw milk, LTLT milk or HHP milk. The first data acquired on a limited number of animals ( $n=3$ /group) show that the absorption of lipids in rats receiving HHP milk tends $(p<0.3)$ to be improved $(7.1 \mathrm{mg} / \mathrm{mL}$ lymph) compared to animals receiving LTLT milk (5.9 $\mathrm{mg} / \mathrm{mL}$ lymph). However, these results are only primary and do not show a significant difference.

\section{Protein Metabolism}

This method of HHP preserves IgAs 64\%, lysozyme 95\%, lactoferrin $100 \%$, caseins was close to $80 \%$, $\alpha$-lactalbumin: $90 \%$.

Cytokines: the highest concentrations of inflammatory cytokines were observed in pasteurized samples compared to the raw and high hydrostatic milk breast milk samples. This difference is probably related to the highest rate of cytolysis during LTLT pasteurization when compared to HHP. 


\subsection{Other Studies with HHP}

Raso [59] studied the different methods of germination of Bacillus cereus spores and therefore used a $250 \mathrm{MPa}$ HHP cycle, added alanine to the milk and then completed a $690 \mathrm{MPa}$ cycle. Under these conditions, substantial protein modification and probably lipase modification were achieved. This shows that it is difficult to destroy Bacillus cereus with a single cycle of HHP and certainly not below $600 \mathrm{MPa}$ and at a temperature below $40{ }^{\circ} \mathrm{C}$, as in our study, in which Bacillus cereus was germinated by an initial cycle at 50-150 MPa and with a temperature of $38^{\circ} \mathrm{C}$.

Jarzynka [60] treated breast milk with HHP at $450 \mathrm{MPa}$ for $15 \mathrm{~min}$, but $10^{2}$ Bacillus cereus remained after treatment. She preserved the breast milk by lyophilization. For the 10 years that we have been using this process in Marmande as a method of conservation, we have not known how the Bacillus cereus remaining after HHP can be sterilized. Moreover, the cost of this treatment would require the cost of a Pascalizator and a freeze-drying machine, i.e., a total of one million euros.

Pitino [61] compared HHP at $500 \mathrm{MPa}$ for $8 \mathrm{~min}, \mathrm{UV}-\mathrm{C}$ at $250 \mathrm{~nm}$ for $25 \mathrm{~min}$ with flash heating and Holder's method. He measured the bacteriology of breast milk, considering milk with less than $10^{3}$ edible germs, which would not be considered sterile. He measured lipase, lactoferrin and lysozyme, which in our procedure, [3] were, respectively, $88 \%, 100 \%$ and $95 \%$. Lipase was absent with LTLT and flash heating, reduced by $48 \%$ with UV-C and maintained with HHP. Lysozyme was reduced by $44 \%$ with flash heating, reduced by $74 \%$ with UV-C and, strangely, was normal with Holder and with HHP, as per our results. Lactoferrin was decreased in all methods: substantially by flash heating $(74 \%)$ and UV-C ( $48 \%$ ) and by $25 \%$ by HHP. Lactoferrin was present at $100 \%$. This study has the limitation of not having made inoculations of Bacillus cereus and admitting $10^{3}$ germs considered as normal values, while in France and most HMB we require $<1 \mathrm{cfu}$. However, among the other methods, UV-C (Christen [62]) and flash heating are disqualified by this study, and HHP preserves the HM (Table 1).

Table 1. Comparison of HHP, LTLT, HTST and UV-C expressed in percentage of raw Human Milk. HHP preserve Biocomponent of HM: Lipase, lactoferrin, lysozyme and IgAs, but Demazeau HHP is the lower pressure with a maximum of $350 \mathrm{MPa}$ and four cycles, one between 50-150 MPa to allow the germination of Bacillus cereus Spores and the last cycle at $350 \mathrm{MPa}$ destroyed the vegetative form; Pitino considered that $<10^{3} \mathrm{cfu}$ is normal, but we consider that only $<1 \mathrm{cfu} / \mathrm{mL}$ is sterile. Also, he did not do a challenge test with more than $10^{6}$ of Bacillus cereus Spores, and we say that with only one cycle, we can destroy it, even with one cycle of $\mathrm{HHP}>600 \mathrm{mPa}$.

\begin{tabular}{|c|c|c|c|c|c|}
\hline & Demazeau HHP & Buffin (LTLT) & MORO (HTST) & Christen (UV-C) & Pitino (HHP) \\
\hline HHP & yes & no & no & no & yes \\
\hline $\max \mathrm{MPa}$ & $350 \times 15^{\prime}$ & & & & $500 \times 8^{\prime}$ \\
\hline Temperature & $38^{\circ} \mathrm{C}$ & $62.5^{\circ} \mathrm{C} \times 30^{\prime}$ & $72{ }^{\circ} \mathrm{C} \times 5-15^{\prime \prime}$ & & $4^{\circ} \mathrm{C}$ \\
\hline UV-C & no & no & no & yes & \\
\hline Lipase & $79-100 \%$ & 0 & 0 & $52 \%$ & $80-100 \%$ \\
\hline Lactoferrin & $100 \%$ & $21 \%$ & $25 \%$ & $40 \%$ & $70 \%$ \\
\hline Lysozyme & $95 \%$ & $84 \%$ & $66 \%$ & $30 \%$ & $100 \%$ \\
\hline IGas & $64 \%$ & $71 \%$ & nd & nd & nd \\
\hline $\begin{array}{l}\text { Bacteriology: } \\
\text { cfu } / \mathrm{mL}\end{array}$ & $\begin{array}{c}<1 \mathrm{cfu} / \mathrm{mL} \\
\text { Sterile }\end{array}$ & $\begin{array}{c}<1 \mathrm{cfu} / \mathrm{mL} \\
\text { sterile }\end{array}$ & $\begin{array}{c}<1 \mathrm{cfu} / \mathrm{mL} \\
\text { sterile }\end{array}$ & & $\begin{array}{c}<10^{3} \mathrm{cfu} / \mathrm{mL} \\
\text { No sterile }\end{array}$ \\
\hline Bacillus cereus & Destroyed & No Destroyed & No Destroyed & No Destroyed & No Destroyed \\
\hline
\end{tabular}

Malinowska-Pańczyk [63] worked on a method with very low HHP pressure (60 to $190 \mathrm{MPa}$ ) and a milk temperature $<0{ }^{\circ} \mathrm{C}$. The pressure treatment at $193 \mathrm{MPa}$ and $-20{ }^{\circ} \mathrm{C}$ on membrane damage bound ATPases and degradation of nucleic acids of E.Coli. However, she did not do the Bacillus cereus challenge test. 


\section{Conclusions}

Holder's pasteurization method, currently used by all HMBs, has many bacteriological defects. It does not destroy Bacillus cereus, which can cause severe preterm infections (Rigourd [64]), and does not preserve lipase, lysozyme, lactoferrin or IgAs (Contador [27]). This is the most common method in HMBs worldwide for treating donated maternal milk. It is the most expensive method if we consider that between $7 \%$ and $14 \%$ (or $1000 \mathrm{~L}$ ) of the milk in France (in an HMB such as in Bordeaux-Marmande or Lyon, which collects more than 10,000 L of milk) is discarded due to the presence of Bacillus cereus. At a rate of $150 € / \mathrm{L}$, this costs $150,000 €$ of losses each year. HHP is the best technique for ensuring sterility when we know that the price of a Pascalizator costs $300,000 €$. For over two years, it has amortized the price of the device. Researchers must study UV-C, Ultrasounds and Cavitation. Using HHP without exceeding $350 \mathrm{MPa}$ and a temperature at $38^{\circ} \mathrm{C}$ allows one to retain almost $100 \%$ of the BSSL lipase, which improves the absorption of not only fats, as demonstrated in our pilot study in rats, but also immune proteins (lactoferrin: $100 \%$; lysozyme: $95 \%$; iGas: $64 \%$ ). In this study, HHP destroyed $10^{6}$ specimens of Bacillus cereus and Staphylococcus aureus and insures safety Human Milk.

Funding: We obtained a grant from the Regional Council of Aquitaine and the research fund of CHU of Bordeaux.

Institutional Review Board Statement: This study concerns anonymous HM samples provided by the Bordeaux HMB and not human.

Informed Consent Statement: When a mother gives her milk to HMB, she signs that she authorizes that her discarded milk might be used for research.

Data Availability Statement: The data details are displayed in the Publication of the studies in the reference $[3,61,62]$ and are summarized in this review paper.

Acknowledgments: In Memoriam: Gerard Demazeau was an Emeritus Professor; for 46 years, an international high-pressure specialist, and created the procedure proposed by our team. This article is an homage to his experience and hard work.

Conflicts of Interest: The author declares no conflict of interest.

\section{References}

1. Gartner, L.M.; Morton, J.; Lawrence, R.A.; Naylor, A.J.; O’Hare, D.; Schanler, R.J.; Eidelman, A.I. Breastfeeding and the use of human milk. Pediatrics 2005, 115, 496-506.

2. Buffin, R.; Hays, S.; Drai, J.; Sarda, M.-N.; Picaud, J.-C. Better Control of Holder Pasteurization Results in Higher Retention of Human Milk Lactoferrin, IgA, and Lysozyme. Front. Pediatr. 2018, 6, 381. [CrossRef]

3. Demazeau, G.; Plumecocq, A.; Lehours, P.; Martin, P.; Couëdelo, L.; Billeaud, C. A New High Hydrostatic Pressure Process to Assure the Microbial Safety of Human Milk While Preserving the Biological Activity of Its Main Components. Front. Public Health 2018, 6, 306. [CrossRef]

4. Evans, T.J.; Ryley, H.C.; Neale, L.M.; Dodge, J.A.; LeWarne, V.M. Effect of storage and heat on antimicrobial proteins in human milk. Arch. Dis. Child. 1978, 53, 239-241. [CrossRef]

5. Koenig, Á.; Diniz, E.M.D.A.; Barbosa, S.F.C.; Vaz, F.A.C. Immunologic Factors in Human Milk: The Effects of Gestational Age and Pasteurization. J. Hum. Lact. 2005, 21, 439-443. [CrossRef]

6. Henderson, T.R.; Fay, T.N.; Hamosh, M. Effect of pasteurization on long chain polyunsaturated fatty acid levels and enzyme activities of human milk. J. Pediatr. 1998, 132, 876-878. [CrossRef]

7. Silvestre, D.; Miranda, M.; Muriach, M.; Almansa, I.; Jareño, E.; Romero, F.J.; Jareo, E. Antioxidant capacity of human milk: Effect of thermal conditions for the pasteurization. Acta Paediatr. 2008, 97, 1070-1074. [CrossRef]

8. Moro, G.E.; Arslanoglu, S. Heat Treatment of Human Milk. J. Pediatr. Gastroenterol. Nutr. 2012, 54, 165-166. [CrossRef] [PubMed]

9. Goldblum, R.M.; Dill, C.W.; Albrecht, T.B.; Alford, E.S.; Garza, C.; Goldman, A. Rapid high-temperature treatment of human milk. J. Pediatr. 1984, 104, 380-385. [CrossRef]

10. Chantry, C.J.; Israel-Ballard, K.; Moldoveanu, Z.; Peerson, J.; Coutsoudis, A.; Sibeko, L.; Abrams, B. Effect of Flash-Heat Treatment on Immunoglobulins in Breast Milk. J. Acquir. Immune Defic. Syndr. 2009, 51, 264-267. [CrossRef]

11. Balci, A.T.; Wilbey, R.A. High pressure processing of milk-the first 100 years in the development of a new technology. Int. J. Dairy Technol. 1999, 52, 149-155. [CrossRef]

12. Chawla, R.; Patil, G.R.; Singh, A.K. High hydrostatic pressure technology in dairy processing: A review. J. Food Sci. Technol. 2010, 48, 260-268. [CrossRef] 
13. Rendueles, E.; Omer, M.; Alvseike, O.; Alonso-Calleja, C.; Capita, R.; Prieto, M. Microbiological food safety assessment of high hydrostatic pressure processing: A review. LWT 2011, 44, 1251-1260. [CrossRef]

14. Cheftel, J.; Culioli, J. Effects of high pressure on meat: A review. Meat Sci. 1997, 46, 211-236. [CrossRef]

15. Martín, M.F.S.; Barbosa-Cánovas, G.V.; Swanson, B.G. Food Processing by High Hydrostatic Pressure. Crit. Rev. Food Sci. Nutr. 2002, 42, 627-645. [CrossRef] [PubMed]

16. Hite, B.H. The effect of pressure in the preservation of milk: A preliminary report. West Va. Agric. For. Exp. Stn. Bull. 1899, 58, 15-35. [CrossRef]

17. Demazeau, G. Un siècle de Hautes Pressions: Développements technologiques et scientifiques. Comptes Rendus Chim. 2008, 128, 933-942. [CrossRef]

18. Hayashi, R. An overview of the use of high pressure in bioscience and biotechnology. Prog. Biotechnol. 1996, 13, 1-6. [CrossRef]

19. Rivalain, N.; Roquain, J.; Demazeau, G. Development of high hydrostatic pressure in biosciences: Pressure effect on biological structures and potential applications in Biotechnologies. Biotechnol. Adv. 2010, 28, 659-672. [CrossRef]

20. Trujillo, A.-J.; Capellas, M.; Saldo, J.; Gervilla, R.; Guamis, B. Applications of high-hydrostatic pressure on milk and dairy products: A review. Innov. Food Sci. Emerg. Technol. 2002, 3, 295-307. [CrossRef]

21. Lullien-Pellerin, V.; Balny, C. High-pressure as a tool to study some proteins' properties: Conformational modification, activity and oligomeric dissociation. Innov. Food Sci. Emerg. Technol. 2002, 3, 209. [CrossRef]

22. Moatsou, G.; Bakopanos, C.; Katharios, D.; Katsaros, G.; Kandarakis, I.; Taoukis, P.; Politis, I. Effect of high-pressure treatment at various temperatures on indigenous proteolytic enzymes and whey protein denaturation in bovine milk. J. Dairy Res. 2008, 75, 262-269. [CrossRef] [PubMed]

23. Viazis, S.; Farkas, B.E.; Allen, J.C. Effects of High-Pressure Processing on Immunoglobulin A and Lysozyme Activity in Human Milk. J. Hum. Lact. 2007, 23, 253-261. [CrossRef]

24. Permanyer, M.; Castellote, C.; Ramírez-Santana, C.; Audí-Miró, C.; Pérez-Cano, F.J.; Castell, M.; López-Sabater, M.C.; Franch, À. Maintenance of breast milk immunoglobulin A after high-pressure processing. J. Dairy Sci. 2010, 93, 877-883. [CrossRef] [PubMed]

25. Viazis, S.; Farkas, B.E.; Jaykus, L.A. Inactivation of Bacterial Pathogens in Human Milk by High-Pressure Processing. J. Food Prot. 2008, 71, 109-118. [CrossRef]

26. Moltó-Puigmartí, C.; Permanyer, M.; Castellote-Bargalló, A.I.; López-Sabater, M.C. Effects of pasteurisation and high-pressure processing on vitamin C, tocopherols and fatty acids in mature human milk. Food Chem. 2011, 124, 697-702. [CrossRef]

27. Contador, R.; Delgado-Adámez, J.; Delgado, F.J.; Cava, R.; Ramírez, R. Effect of thermal pasteurisation or high pressure processing on immunoglobulin and leukocyte contents of human milk. Int. Dairy J. 2013, 32, 1-5. [CrossRef]

28. Delgado, F.J.; Contador, R.; Álvarez-Barrientos, A.; Cava, R.; Delgado-Adámez, J.; Ramírez, R. Effect of high pressure thermal processing on some essential nutrients and immunological components present in breast milk. Innov. Food Sci. Emerg. Technol. 2013, 19, 50-56. [CrossRef]

29. Johnston, D.E. High Pressure Processing of Foods; Ledward, D.A., Johnston, D.E., Earnshaw, R.G., Hasting, A.P.M., Eds.; University Press: Loughborough/Nottingham, UK, 1995; pp. 99-121.

30. Devi, A.F.; Buckow, R.; Hemar, Y.; Kasapis, S. Structuring dairy systems through high pressure processing. J. Food Eng. 2013, 114, 106-122. [CrossRef]

31. Martínez-Rodríguez, Y.; Acosta-Muñiz, C.; Olivas, G.I.; Guerrero-Beltrán, J.; Rodrigo-Aliaga, D.; Mújica-Paz, H.; Welti-Chanes, J.; Sepulveda, D.R. Effect of high hydrostatic pressure on mycelial development, spore viability and enzyme activity of Penicillium Roqueforti. Int. J. Food Microbiol. 2014, 168-169, 42-46. [CrossRef]

32. Law, A.J.R.; Leaver, J.; Felipe, X.; Ferragut, V.; Pla, R.; Guamis, B. Comparison of the Effects of High Pressure and Thermal Treatments on the Casein Micelles in Goat's Milk. J. Agric. Food Chem. 1998, 46, 2523-2530. [CrossRef]

33. Russo, D.; Ortore, M.G.; Spinozzi, F.; Mariani, P.; Loupiac, C.; Annighofer, B.; Paciaroni, A. The impact of high hydrostatic pressure on structure and dynamics of $\beta$-lactoglobulin. Biochim. Biophys. Acta Gen. Subj. 2013, 1830, 4974-4980. [CrossRef]

34. Gosch, T.; Apprich, S.; Kneifel, W.; Novalin, S. A combination of microfiltration and high pressure treatment for the elimination of bacteria in bovine colostrum. Int. Dairy J. 2014, 34, 41-46. [CrossRef]

35. Buchheim, W.; Abou El Nour, A.M. Induction of milk fat crystallisation in the emulsified state by high hydrostatic pressure. Eur. J. Lipid Sci. Technol. 1992, 94, 369-373.

36. Gervilla, R.; Felipe, X.; Ferragut, V.; Guamis, B. Effect of High Hydrostatic Pressure on Escherichia coli and Pseudomonas fluorescens Strains in Ovine Milk. J. Dairy Sci. 1997, 80, 2297-2303. [CrossRef]

37. Buffa, M.; Guamis, B.; Pavia, M.; Trujillo, A.J. Lipolysis in cheese made from raw, pasteurised or high-pressure-treated goats' milk. Int. Dairy J. 2001, 11, 175-179. [CrossRef]

38. López-Fandiño, R.; Carrascosa, A.; Olano, A. The Effects of High Pressure on Whey Protein Denaturation and Cheese-Making Properties of Raw Milk. J. Dairy Sci. 1996, 79, 929-936. [CrossRef]

39. Gervilla, R.; Ferragut, V.; Guamis, B. High hydrostatic pressure effects on colour and milk-fat globule of ewe's milk. J. Food Sci. 2001, 66, 880-885. [CrossRef]

40. Mussa, D.; Ramaswamy, H. Ultra High Pressure Pasteurization of Milk: Kinetics of Microbial Destruction and Changes in Physico-chemical Characteristics. LWT 1997, 30, 551-557. [CrossRef] 
41. Needs, E.C.; Capellas, M.; Bland, A.P.; Manoj, P.; MacDougal, D.; Paul, G. Comparison of heat and pressure treatments of skim milk, fortified with whey protein concentrate, for set yogurt preparation: Effects on milk proteins and gel structure. J. Dairy Res. 2000, 67, 329-348. [CrossRef]

42. Cheftel, J.C. Effects of High Hydrostatic Pressure on Food Constituents: An Overview. In High Pressure and Biotechnology; Balny, C., Hayashi, R., Heremans, K., Masson, P., Eds.; Colloque INSERM John Libbey Eurotext, Ltd.: London, UK, 1992; pp. 195-209.

43. García-Graells, C.; Masschalck, B.; Michiels, C.W. Inactivation of Escherichia coli in Milk by High-Hydrostatic-Pressure Treatment in Combination with Antimicrobial Peptides. J. Food Prot. 1999, 62, 1248-1254. [CrossRef] [PubMed]

44. Smelt, J.M. Recent advances in the microbiology of high pressure prosing. Trends Food Sci. Technol. 1998, 9, 152-158. [CrossRef]

45. Rivalain, N.; Roquain, J.; Boiron, J.-M.; Maurel, J.-P.; Largeteau, A.; Ivanovic, Z.; Demazeau, G. High hydrostatic pressure treatment for the inactivation of Staphylococcus aureus in human blood plasma. New Biotechnol. 2012, 29, 409-414. [CrossRef] [PubMed]

46. Kolakowski, P.; Reps, A.; Dajnowiec, F.; Szczepek, J.; Porowski, S. Effect of High Pressures on the Microflora of Raw Cow's Milk. In Process Optimisation and Minimal Processing of Foods; Oliveira, J.C., Oliveira, F.A.R., Eds.; European Commission: Leuven, Belgium, 1997; pp. 46-50.

47. Alpas, H.; Bozoglu, F. The combined effect of high hydrostatic pressure, heat and bacteriocins on inactivation of foodborne pathogens in milk and orange juice. World J. Microbiol. Biotechnol. 2000, 16, 387-392. [CrossRef]

48. Morgan, S.M.; Ross, R.P.; Beresford, T.; Hill, C. Combination of hydrostatic pressure and lacticin 3147 causes increased killing of Staphylococcus and Listeria. J. Appl. Microbiol. 2000, 88, 414-420. [CrossRef] [PubMed]

49. Rigaldie, Y.; Lemagnen, G.; Largeteau, A.; Larrouture, D.; Abba, M.; Haller, R.; Grislain, L.; Demazeau, G. Pharmaceuticals Perspectives of High Pressure: A Soft Tool for Sterilization of Fragile Drugs. Defect Diffus. Forum 2002, 208-209, 55-58. [CrossRef]

50. Reineke, K.; Mathys, A.; Heinz, V.; Knorr, D. Mechanisms of endospore inactivation under high pressure. Trends Microbiol. 2013, 21, 296-304. [CrossRef]

51. Rocha-Pimienta, J.; Martillanes, S.; Ramirez, R.; Garcia-Parra, J.; Delgado-Adamez, J. Bacillus cereus spores and Staphylococcus aureus sub. aureus vegetative cells inactivation in human milk by high-pressure processing. Food Control. 2020, 113, 107212. [CrossRef]

52. Norton, T.; Sun, D.-W. Recent Advances in the Use of High Pressure as an Effective Processing Technique in the Food Industry. Food Bioprocess Technol. 2008, 1, 2-34. [CrossRef]

53. Silva, J.; Luan, P.; Glaser, M.; Voss, E.W.; Weber, G. Effects of hydrostatic pressure on a membrane-enveloped virus: High immunogenicity of the pressure-inactivated virus. J. Virol. 1992, 66, 2111-2117. [CrossRef] [PubMed]

54. Nakagami, T.; Shigehis, T.; Ohmori, T.; Taji, S.; Hase, A.; Kimura, T.; Yamanishi, K. Inactivation of herpes viruses by high hydrostatic pressure. J. Virol. Methods 1992, 38, 255-261. [CrossRef]

55. Kingsley, D.H.; Hoover, D.G.; Papafragkou, E.; Richards, G.P. Inactivation of Hepatitis A Virus and a Calicivirus by High Hydrostatic Pressure. J. Food Prot. 2002, 65, 1605-1609. [CrossRef]

56. Pontes, L.; Cordeiro, Y.; Giongo, V.; Villas-Boas, M.; Barreto, A.; Araújo, J.R.; Silva, J.L. Pressure-induced formation of inactive triple-shelled rotavirus particles is associated with changes in the spike protein VP4. J. Mol. Biol. 2001, 307, 1171-1179. [CrossRef] [PubMed]

57. Landolfo, S.; Gariglio, M.; Gribaudo, G.; Lembo, D. The human cytomegalovirus. Pharmacol. Ther. 2003, 98, 269-297. [CrossRef]

58. Gaspar, L.P.; Terezan, A.F.; Pinheiro, A.S.; Foguel, D.; Rebello, M.A.; Silva, J. The Metastable State of Nucleocapsids of Enveloped Viruses as Probed by High Hydrostatic Pressure. J. Biol. Chem. 2001, 276, 7415-7421. [CrossRef] [PubMed]

59. Raso, J.; Góngora-Nieto, M.M.; Barbosa-Cánovas, G.V.; Swanson, B.G. Influence of several environmental factors on the initiation of germination and inactivation of Bacillus cereus by high hydrostatic pressure. Int. J. Food Microbiol. 1998, 44, 125-132. [CrossRef]

60. Jarzynka, S.; Strom, K.; Barbarska, O.; Pawlikowska, E.; Minkiewicz-Zochniak, A.; Rosiak, E.; Oledzka, G.; Wesolowska, A. Combination of High-Pressure Processing and Freeze-Drying as the Most Effective Techniques in Maintaining Biological Values and Microbiological Safety of Donor Milk. Int. J. Environ. Res. Public Health 2021, 18, 2147. [CrossRef]

61. Pitino, M.A.; Unger, S.; Doyen, A.; Pouliot, Y.; Aufreiter, S.; Stone, D.; Kiss, A.; O'Connor, D.L. High Hydrostatic Pressure Processing Better Preserves the Nutrient and Bioactive Compound Composition of Human Donor Milk. J. Nutr. 2019, 149, 497-504. [CrossRef] [PubMed]

62. Christen, L.; Lai, C.T.; Hartmann, B.; Hartmann, P.E.; Geddes, D.T. The Effect of UV-C Pasteurization on Bacteriostatic Properties and Immunological Proteins of Donor Human Milk. PLoS ONE 2013, 8, e85867. [CrossRef]

63. Lewin, A.; Quach, C.; Rigourd, V.; Picaud, J.C.; Perreault, T.; Frange, P.; Domingo, M.-C.; Lalancette, C.; Delage, G.; Germain, M. Bacillus cereus infection in neonates and the absence of evidence for the role of banked human milk: Case reports and literature review. Infect. Control Hosp. Epidemiol. 2019, 40, 787-793. [CrossRef]

64. Malinowska-Pańczyk, E.; Kołodziejska, I. The Effect of High Pressure and Subzero Temperature on Gelation of Washed Cod and Salmon Meat. Food Technol. Biotechnol. 2017, 55, 405-412. [CrossRef] [PubMed] 